\title{
A Study on the Psychological and Role Quality of Teachers of Public Basic Courses in Colleges and Universities in the Age of MOOCs*
}

\author{
Li Wang \\ Tianjin Agricultural University \\ Tianjin, China 300384
}

\begin{abstract}
Psychology of higher education is a science that studies the basic psychological laws of learning and teaching in the context of college and university. From the perspective of teachers' psychology, this paper analyzes the reasons why the teachers of public courses in colleges and universities are not positive in the face of "MOOCs", and on this basis, the author summarizes the quality factors that the teachers of public basic courses need to carry out in the teaching of "MOOCs" to provide some reference for them to shift their roles, change their psychology and embrace the teaching of MOOCs.
\end{abstract}

Keywords-MOOCs; teachers' psychology; quality

\section{INTRODUCTION}

Chinese universities have set off a large-scale upsurge of online open courses. Public basic courses in colleges and universities are very suitable for making MOOCs. However, at present, many teachers of these courses in colleges and universities have not actively engaged in this upsurge. Some of teachers are old-fashioned and reject new teaching methods; and some of them are too lazy to shift their traditional methods. Motivation influences behavior. Therefore, from the perspective of higher education psychology, this study analyses the psychology of teachers of public basic courses in colleges and universities. Teachers should not only influence students in accordance with educational guide line, policies and principles, but also be influenced by students. Humanistic psychology emphasizes that learning is a process in which learners develop their potentials and realize their own values. Teachers' teaching shall be first faced with a living person and the rich inner world of students, rather than inanimate things such as textbooks, teaching methods, homework and scores. In such an era of rapid development of micro media, students tend to have shorter attention time and fragmented thinking. In this context, palm media have become their favors. Therefore, teachers should actively understand the teaching of MOOCs in order to meet the current psychological development of students.

Teachers are the main designers and implementers of

*Fund Program: "Research on the Coping Strategies of Teachers of Public Basic Courses in Colleges and Universities under the Background of MOOC" of Project of Funding Basic Scientific Research Business in Tianjin Colleges and Universities (2016JSYB05)
MOOCs teaching. Their participation and intentions directly affect the quality of the teaching. Then, how to guide teachers to overcome inertia and actively welcome the teaching of MOOCs?

\section{PSYCHOLOGY OF TEACHERS}

\section{A. Cultivating the Motivation of MOOCs Education}

Compared with the traditional model, the core content of MOOC is learner-centered. Motivation is the driving factor of all actions. If a teacher wants to change his teaching methods, it's necessary for him to first have the motivation to do a good job in education, and then he can actively evaluate, feedback and regulate his teaching activities. The strong interest in educational work is an important motive force for teachers to creatively complete educational work. First of all, they should have a wide range of interests. The development of science and the progress of mankind have brought many new things to education, which requires teachers to care about and understand such new knowledge. The purpose of human beings is multifaceted, so, in response, what teachers care about should also be multifaceted. Secondly, due to the emergence of new things, the scope of interest of students is becoming wider and wider, so that it is difficult for teachers who are uninformed and have little knowledge to arouse students' thirst for knowledge and cultivate a large number of talents with wide learning. Thirdly, teachers should have a central interest. Teachers' central interest refers to their interest in students' physical and mental development and in the study of the subjects they teach. This interest not only enables teachers to approach and understand students, but also encourages them to actively study textbooks, educational methods and creative work. Combining central interest with multiple interests is an essential psychological condition for teachers to creatively complete their educational work.

\section{B. Changing Teachers' Educational Concepts}

Teachers' different attitudes towards things will affect their way of dealing with problems. And those with diverse educational concepts will adopt distinct teaching behaviors. If a teacher thinks that he should be in the absolute dominant position in the classroom, then he will fail to mobilize the enthusiasm of students, so that the students won't be allowed 
to fully express their views. College students living in modern society not only hope that teachers can become their guide to help them enter the palace of science, but also hope that teachers can be sincere, frank friends, with whom they can share everything. If a teacher loves, sympathizes with, treats equally his students and persists in carrying out ideological education patiently and meticulously for students, the class collective he leads may become a group of unity and friendship, and he may also become a friend and confidant of the students. So, the students may also tell him what they think. In order to play a good role as a friend of college students, firstly, teachers should dilute their teacher status, consider more equality with students and respect students. Secondly it's crucial for teachers to treat all students in an equal way, listen carefully to their opinions and suggestions. It will be better to understand and recognize students' different opinions as well as differences, treating them sincerely.

\section{Understanding the Level of Students' Psychological Development}

It is an important content to fully understand students' psychological development level and accurately grasp the starting point of teaching. The level of students' psychological development mainly refers to their knowledge preparation, ability, physical and mental maturity and learning motivation. The level of students' knowledge and ability and their preparation for learning are the basis of teachers' teaching. Only on the basis of students' psychological development, can communication between teaching and learning be possible.

Students are the subject of information processing and the active constructor of meaning, instead of the role of passive recipient of external stimuli and the object of inculcation. Students are regarded as thinkers who form realistic theories. Learning is a process controlled internally by learners. Therefore, learners' autonomy and go-aheadism should be encouraged and accepted. Moreover, they shall be considered as people with will and purpose, and should be encouraged to question and cultivate curiosity. Because of this, the teaching goal has great flexibility. It's unwise for teachers to impose what they know about on learners forcedly. Conversely, teachers should make consultation with learners to finalize a decision, or encourage learners to do adjustment freely by themselves in the learning process. This is consistent with the concept of MOOCs.

\section{Role Change of Teachers in MOOC}

The purpose of applying the role-changing technology is to transform the teacher from an instructor to a teaching researcher, making them carry out scientific research on their teaching process, so as to form a correct educational concept, improve the consciousness and initiative of participating in educational research, treat their teaching process as their own research object, and observe, examine, think about, adjust it to ultimately improve their teaching monitoring capabilities. The specific methods and contents of the role-changing technology include attending experts' lectures, listening to demonstration classes, and participating in educational research. Only when teachers become teaching researchers will they actively monitor their own teaching processes and actively participate in the teaching of MOOC.

Modern teachers must also become researchers in teaching. The basic principles of teaching and learning are only applicable for general situations, and no theory can tell teachers how to conduct their teaching process under a certain condition. To make decisions in teaching, teachers should take into account these specific background conditions. Teachers must study their own teaching process and become both the educator and the teaching researcher, so that they can flexibly solve various practical problems in teaching based on certain theories.

\section{E. Establishing the Relationship in Which Teaching Benefits Teachers as Well as Students}

A core aspect of MOOC teaching is to reorganize the relationship between teaching and learning, with students as the main body and teachers as the guiding roles. In the process of teaching design, teachers should always maintain a rational mind and put the service for students in the first place. For teachers, the design of teaching is to well plan their own teaching processes before class. The purpose of planning is to enable students to achieve their goals as soon as possible. Teachers should, according to their own characteristics, under the premise of providing conditions and space for the development of students, flexibly choose teaching methods and strategies within their control and achieve their teaching objectives in an optimal way.

Teachers should not be regarded as the roles to give knowledge to students, but should be regarded as the roles to promote students to conduct various learning activities. Teachers should help and facilitate students in their meaning construction, but should not only give knowledge to and indoctrinate them. Teachers should be good at causing imbalances in students' concepts, attach great importance to the diagnosis and correction of students' mistakes, pay full attention to the specificity of each student's cognition, strive to cultivate students' self-consciousness and metacognitive ability and mobilize students' enthusiasm in learning, and play a good role in the organization and orientation of teaching activities. In addition, the educator is the coach for problem solving and the analyst of strategies, so he should pay great attention to the self-conscious reflection and necessary update of his own views of science and teaching.

\section{F. Innovation}

Teaching is an art, and art will be lifeless without innovation. Any discipline has its own characteristics. Any teacher has his own teaching experience and teaching style. And any student has his/her own particularity. Therefore, when making the teaching design, teachers need to combine different teaching contents, different course forms, different selffeatures, and students' ability foundation and cognitive style to design teaching objectives, determine teaching methods, and select evaluation methods. When making their teaching designs, teachers should not follow the old rules, stick to the rules, but should make bold innovations. If the teachers of public basic courses in colleges and universities always use the 
old teaching materials and apply old teaching modes, they will inevitably be abandoned by the times.

\section{The QuAlity OF MOOC TEACHERS' Role}

When the teaching of MOOCs develops to a mature stage, in terms of teachers of public basic courses in colleges and universities, some of them become famous teachers, some become assistants, and some become technicians [2] in MOOCs. The courses have changed from traditional knowledge-based type to diversified types [3], which requires teachers to have various abilities.

\section{A. Originality}

Although there are many cases of MOOCs on the network platform now, the MOOCs produced by each team cannot be completely same, which requires MOOCs teachers to have certain originality. Teachers can keep up with the development of education only by constantly exploring and innovating educational ideas, forms and methods. There is no exactly the same educational situation for teachers, and the best educational model that is universally applicable to any situation does not exist. In the education process, teachers cannot fully copy the experience of others nor completely apply their previous experience. New students, new environment and new courses all require teachers to constantly seek new methods and approaches. The education object is each student with rich personality. There is no one principle and method of education applicable to any student. This requires teachers to adopt different methods based on different objects, teach students in accordance with their aptitude, and creatively education each student.

\section{B. Intense Feelings}

MOOCs are online courses, and teachers do not get along with their students in a physical space, which demands teachers to be more enthusiastic than in the classroom, so that they can communicate with students through the screen, and students can be more interested in learning this course. A teacher who loves education career deeply will be willing to devote himself to education career and nurture a new generation carefully. Teachers' emotion is related to their sense of responsibility, obligation, honor and pride in educating the younger generation. A teacher who is full of sincere love for students will care about the growth of students at any time any place and constantly perfect his education level. Therefore, it is the duty of a teacher to love his students. However, teachers' love for students should not be regarded as just treating them kindly and attentively. The content of teachers loving students should include the following aspects: teachers should understand students' condition, teach students in accordance with their aptitude, respect and maintain students' self-esteem; teachers should trust students, try various to enhance students' self-confidence, encourage them and make strict requirements on them. A teacher who is full of love for his subject will deepen his understanding of the textbooks and will teach each lesson emotionally, so that students can have corresponding emotional experience, feel and understand the textbooks more deeply.

\section{Strong Wills}

There will be many difficulties in the process of MOOCs production, such as production technology, low course selection rate, inconsistent learning effects and ideals, and so on. Not fearing difficulties, perseverance, constancy, and never yielding in spite of reverses are the internal forces that teachers directly influence students. Teachers with this will quality can maintain strong energy in education practice, overcome internal and external difficulties, and cultivate students' sentiment and fearlessness by their own behaviors. Teachers should maintain an optimistic attitude and engage in education in a positive and full mood, and discover and solve problems independently. Teachers should not be panic even in difficult conditions, and can exert their strength under urgent circumstances. This is the quality that creative work must possess.

\section{CONCLUSION}

Teachers of public basic courses in colleges and universities are a huge team. The MOOCs teaching is growing vigorously. Only by opening and expanding their minds and actively welcoming MOOCs from the mental motivation can they transform the teaching from knowledge-oriented type to diversified types and become teachers who truly adapt to MOOCs teaching.

\section{REFERENCES}

[1] http://paper.jyb.cn/zgjyb/html/2018-05/08/content_498664.htm?div=-1. (in Chinese)

[2] Wang Songjie. Research on Challenges and Countermeasures of Methods of Ideological and Political Education for College Students in MOOC Era [D]. Zhengzhou University, 2017. (in Chinese)

[3] Guo Jiao. Opportunities, Challenges and Strategies for Local Colleges and Universities Brought by "MOOCs" [J]. China Adult Education, 2017 (08): 91-93. (in Chinese) 